\title{
Relevance of Viral Phenotype in the Early AIDS Outcome of Pediatric HIV-1 Primary Infection
}

\author{
JULIETA KOPKA, MARCELO BATALLA, ANDREA MANGANO, DEBORA MECIKOVSKY, \\ ROSA BOLOGNA, AND LUISA SEN \\ Laboratorio de Biología Celular y Retrovirus [J.K., M.B., A.M., L.S.] and Servicio de Infectología [D.M., \\ R.B.], Hospital Nacional de Pediatría "Prof. Dr. J. P. Garrahan", Buenos Aires, Argentina
}

\begin{abstract}
In infants the clinical course of HIV-1 infection is bimodal, differing considerably from that of adults. The effect of HIV-1 phenotypic features and plasma viral load on the clinical course of infection has been well established in adults, whereas in children it remains controversial. The aim of this study was to prospectively evaluate the effect of HIV-1 replication phenotypes during the first year of primary infection in the development of premature immunosuppression and early pediatric AIDS. In 62 vertically infected children replication rates of HIV-1 isolates from primary cultures and syncytium-inducing capability in MT-2 cell line were evaluated, together with plasma viral load. It was observed that rapid replication rate and syncytium-inducing phenotype accelerate the early onset of pediatric AIDS $(p=0.02$ and $p=0.04$, respectively). Rapid replication kinetics was the only significantly independent variable for early clinical outcome (risk ratio, 2.48; $p=0.02$ ). Both viral properties contributed to rapid $\mathrm{CD} 4{ }^{+} \mathrm{T}$-cell depletion $(p=0.05$ for rapid replication rate,
\end{abstract}

$p=0.01$ for syncytium-inducing viral phenotype). Plasma viral burden higher than $5.5 \log _{10}$ copies $/ \mathrm{mL}$ after 6 mo of age tended to be associated with disease progression. In conclusion, initial HIV - 1 biologic features in pediatric primary infection by vertical transmission may influence the progression to early immunosuppression and development of AIDS. (Pediatr Res 52: 475-480, 2002)
$\bigcirc \bigcirc$
SI, syncytium-inducing
NSI, non-syncytium-inducing
PBMC, peripheral blood mononuclear cells
PHA, phytohemagglutinin
ZDV, zidovudine
M-tropic, macrophage-tropic
T-tropic, T cell-line-tropic
Ag, antigen

Pediatric HIV-1 infection acquired by vertical transmission follows a bimodal clinical course. Approximately one third of infected children develop AIDS within the first $2 \mathrm{y}$ of life, and the remaining progress clinically more slowly, representing the second peak of pediatric AIDS (1-3). The reason for the dichotomy is still unclear. Timing of viral transmission is considered the main cause since intrauterine transmission has been associated with a more rapid disease progression than intrapartum or breast-feeding transmission (2). In addition, viral characteristics (4-6) and host genetic

Received April 25, 2001; accepted March 7, 2002.

Correspondence: Luisa Sen, M.D., Laboratorio de Biología Celular y Retrovirus, Hospital Nacional de Pediatría "Prof. Dr. J. P. Garrahan", Combate de los Pozos 1881, 1245 Ciudad de Buenos Aires, Argentina; e-mail: 1sen@garrahan.gov.ar

Supported by Agencia Nacional de Promoción Científica y Tecnológica, award no. 2167, "Ramón Carrillo-Arturo Oñativia" Fellowship 2000, and Fundación "Alberto J. Roemmers" funds.

DOI: 10.1023/01.PDR.0000028056.74614.E0 background (7) may also affect the clinical outcome of AIDS.

AIDS pathogenesis is widely variable among infected people. In vitro biologic features of HIV-1 isolates and plasma viral burden have been reported to play an important role in disease outcome of infected adults $(4-6,8)$. M-tropic R5, NSI HIV-1 strains that predominate during the asymptomatic period of infection, are the phenotypes preferentially transmitted $(9,10)$. As the infection progresses, in approximately half of the patients HIV-1 switches from M-tropic to either T-tropic (X4) or dual-tropic (R5X4) SI, which is followed by a rapid decline of circulating $\mathrm{CD} 4^{+} \mathrm{T}$-cell counts and progression to AIDS (11-14). Usually, M-tropic NSI strains have an in vitro slower replication rate with a lower yield of virus than T-tropic SI viral isolates $(4,6)$. Although most HIV-1 phenotypic studies have been conducted in adults, it is generally accepted that they may similarly affect the clinical outcome of HIV-1infected children. Few reports with a limited number of infants 
analyzed have shown discordant results (15-20); thus the impact of replication phenotypes in pediatric AIDS remains to be elucidated.

The aim of this study was to evaluate the effect of HIV-1 replication phenotypes and plasma viral burden on immunosuppression and disease progression in a cohort of vertically infected children during HIV-1 primary infection.

\section{METHODS}

Patients. The study included 62 HIV-1 vertically infected children who were referred to the "Hospital de Pediatría Garrahan." Buenos Aires, Argentina, between May 1997 and March 2000 for diagnosis of perinatal HIV-1 infection. Informed consent from the parents or legal guardians was obtained. The study was reviewed and approved by the ethics committee of the hospital. The median age of the children at the time of the viral study was 6 mo (range, $0.5-14 \mathrm{mo}$ ) with a sex distribution of 29 boys and 33 girls. According to the AIDS Clinical Trials Group (ACTG) 076 protocol (21), ZDV prophylaxis of mother-infant pairs (a three-part regimen) was given to $16(26 \%)$ children, partially (mother or child) given to $10(16 \%)$ infants, $34(55 \%)$ infants did not receive ZDV, and information from $2(3 \%)$ infants was unavailable. At the time of entry in the study, none of the children was receiving prophylactic ZDV or other antiretroviral therapy.

Of the 62 infants, 55 were prospectively followed-up at our hospital for a mean time $( \pm \mathrm{SD})$ of $16.8 \pm 7.7$ mo (range, 4-36 mo). After HIV-1 infection diagnosis, seven children were lost and excluded from the analysis of disease progression.

$\mathrm{CD}^{+}{ }^{+}$-cell counts obtained with or close to the virologic samples were available in 51 children. $\mathrm{As}^{\mathrm{CD}} 4^{+} \mathrm{T}$-eell count normally drops with age in children, age-adjusted $\mathrm{CD} 4^{+} \mathrm{T}$-cell counts were expressed as a percentage of the median $\mathrm{CD} 4^{+}$ T-cell value calculated for healthy children in various age groups (22). Clinical and immunologic stages were established according to the 1994 criteria of the US Centers for Disease Control and Prevention classification for children (23). At the entry in the study, the clinical categories of the infants were as follows: $31(50 \%)$ children stage $\mathrm{N}$ or A, $7(11 \%)$ stage B, and $24(39 \%)$ stage C. We defined early disease progression as children progressing to AIDS within the first year of life, and immunosuppression as $\mathrm{CD}^{+}{ }^{+}$T-cell counts below $20 \%$ of normal. Four infants with early AIDS outcome died during the study at 4, 5, 7, and 11 mo of age.

Viral load measurements. Plasma viral burden was determined by HIV-1 RNA QT Nuclisens (Organon Teknika, Boxtel, The Netherlands) or with Amplicor HIV-1 Monitor test (Roche Diagnostic Systems, Branchburg, U.S.A.) according to the manufacturer's instructions.

Virus isolation. HIV-1 was isolated by cocultivation as previously described by Hollinger et al. (24). Briefly, 3-6 $\times 10^{6}$ PBMC from the patients were cocultured with an equal amount of PBMC obtained from HIV-seronegative blood donors, prestimulated for 24 to $72 \mathrm{~h}$ with PHA $(5 \mu \mathrm{g} / \mathrm{mL}$ Difco Laboratories, Detroit, MI, U.S.A.), in RPMI 1640 medium (Invitrogen, Carlsbad, CA, U.S.A.) supplemented with 20\% fetal bovine serum (Invitrogen), $5 \mathrm{U} / \mathrm{mL}$ IL-2 (human natural, Invitrogen), and $10 \mu \mathrm{g} / \mathrm{mL}$ gentamicin (Invitrogen). The cultures were maintained for over a month, and cell-free supernatants were collected on d 2 to 5 and twice a week thereafter. Every week, fresh PHA-stimulated donor cells were added to the cultures. Viral stocks were stored at $-80^{\circ} \mathrm{C}$ for further infectivity assays.

Viral replication kinetics was determined in PBMC culture supernatants by measuring p24 Ag with a commercial ELISA (HIVAg 1 Monoclonal; Abbott Laboratories, U.S.A.). According to the time of p24 Ag detection and maximum level of production throughout the cell culture, HIV-1 isolates were classified as rapid (R) or slow (S) and high (H) or low (L). R replication rate was defined when $\mathrm{p} 24 \mathrm{Ag}$ was detected within the first $5 \mathrm{~d}$ of being cultured and $\mathrm{S}$ when the lag phase was 6 or more days. When $\mathrm{p} 24 \mathrm{Ag}$ production was higher than 20,000 $\mathrm{pg} / \mathrm{mL}$ during the month of culture, HIV-1 isolates were considered $\mathrm{H}$; by contrast, viral isolates with lower outputs were defined as L.

Syncytium formation assay. The assay for syncytium formation was performed as described by Japour et al. (25). Briefly, supernatants from HIV-1-positive cocultures (p24 Ag $>200 \mathrm{pg} / \mathrm{mL}$ ) were added to four wells containing $5 \times 10^{4}$ MT-2 cells/well in RPMI 1640 medium (Invitrogen) supplemented with $10 \%$ fetal bovine serum (Invitrogen) and 10 $\mu \mathrm{g} / \mathrm{mL}$ gentamicin (Invitrogen) in 96-well plates. SI primary isolates from patients were used as positive controls in each assay, and wells without virus served as negative controls. Syncytium formation of the culture was examined microscopically at 3- to 4-d intervals for 14-21 d. After each examination, half of the culture volume was replaced with fresh medium. SI was scored when an infected well had five or more syncytia. At the end of the culture, the cells were recovered, washed twice with PBS, and HIV-1 proviral DNA was amplified directly on cell lysates as described by Albert and Fenyo (26).

To assure the infectious potential of the viral inoculum added to the MT-2 cells, in particular of the isolates that were NSI, a parallel infectivity assay was performed adding the same viral inoculum to duplicate wells in 96-well plates containing $2 \times 10^{5}$ PHA-stimulated PBMC from an HIVseronegative blood donor. After an overnight incubation, cells were washed twice with PBS and refilled with fresh medium (RPMI 1640 supplemented with 10\% fetal bovine serum, 5 $\mathrm{U} / \mathrm{mL}$ IL-2, and $10 \mu \mathrm{g} / \mathrm{mL}$ gentamicin). On $\mathrm{d} 7$, half of the culture volume was exchanged, and on d 14, p24 Ag production was measured in culture supernatants. When the viral inoculum was able to productively infect PBMC, and no syncytia in MT-2 cells were observed by microscopic examination, the viral isolate was scored as NSI.

Statistical analysis. Comparison of biologic properties of the viral isolates and immunologic features of HIV-1-infected infants in relation to disease progression were statistically analyzed by either Fisher's exact test or $\chi^{2}$ test. When normal distribution of the variables and no significant difference of variances were fulfilled, unpaired $t$ test was used to compare the differences for continuous variables $\left(\mathrm{CD}^{+}{ }^{+} \mathrm{T}\right.$-cell counts, plasma viral load, first day and maximum level of p24 Ag 
detection in cultures) in relation to clinical stage. Spearman's correlation coefficient was used to evaluate a possible association between plasma viral load and the day of appearance of p24 Ag in viral cultures. To estimate the cumulative proportion of children who progressed to AIDS we performed KaplanMeier analysis. Differences in rates of progression were tested by the $\log$ rank test. Multivariate analysis was performed by Cox proportional hazard regression model to determine the risk ratio to AIDS progression for the different features analyzed. Statistical significance for all tests was considered when $p \leq$ 0.05 .

\section{RESULTS}

Biologic features of HIV-1 isolates. Replication kinetics of the virus was measured in 60 infants. Thirty-five (58\%) showed $\mathrm{R}$ replication rate and $25(42 \%) \mathrm{S}$ replication rate. On the other hand, in $38(63 \%)$ of the infants HIV-1 production was $\mathrm{H}$ and in $22(37 \%)$ was $\mathrm{L}$. The combination of both replication features $(\mathrm{R} / \mathrm{S}$ and $\mathrm{H} / \mathrm{L})$ revealed a significant association between them ( $p<0.0001$, Fisher's exact test $)$ and is illustrated in Table 1 . $\mathrm{R}$ viral isolates were associated with $\mathrm{H}$ virus production, whereas $\mathrm{S}$ strains were related with $\mathrm{L}$ virus production.

HIV-1 isolates from 62 infants were evaluated for SI capability. Eighteen percent were able to induce syncytium formation (SI); $75 \%$ of SI strains were isolated within the first 5 mo of life. To assure infection of MT-2 cells by SI strains versus noninfection by NSI viruses, we examined the presence of HIV-1 provirus by PCR on MT-2 cells cultured with the studied viral isolates. HIV-1 provirus was present in MT-2 cells inoculated with all SI strains but also with one NSI strain. This finding suggests either 1) that the number of SI strains in the viral isolate is too low to induce syncytium formation, or 2) the existence of a viral strain able to infect MT-2 cells without causing syncytia. For further evaluation, the discrepant HIV-1 isolate was excluded from the study. SI and NSI viral strains did not significantly differ in their replication rates.

Replication phenotype and HIV-1 disease progression. Clinical follow-up was prospectively recorded in 55 HIV-1 infected children, and $64 \%$ of them developed AIDS before 12 mo of age. Twenty-two infants received ZDV prophylactic therapy. The number of patients who developed AIDS within the first year of life did not differ significantly whether or not they received ZDV (data not shown).

To evaluate the impact of HIV-1 replication phenotypes on early onset of AIDS, children were divided into two groups on the basis of whether they developed AIDS or not during the first year of life. Results are summarized in Table 2. Among the children with SI isolates, 91\% developed AIDS during the first year of life, which was significantly higher than the $56 \%$ of children who harbored NSI viral strains ( $p=0.04$, Fisher's exact test; Table 2). Kaplan-Meier analysis of SI and NSI phenotypes for AIDS outcome showed no significant differences (Fig. 1A), although children with SI virus tended to progress to AIDS more rapidly than those with NSI isolates ( $p$ $=0.06, \log$ rank test).

Although early isolation of SI viral strains in pediatric HIV-1 primary infection seems to be associated with rapid progression to AIDS, a high proportion of infants harboring NSI viruses developed early AIDS as well. These results suggest that besides SI viral phenotype, other factors may influence pediatric HIV-1 clinical outcome. Considering the replication kinetics of viral isolates, two thirds of the children who developed AIDS within the first year of life harbored viruses with $\mathrm{R}$ replication rate compared with less than one third of infants without early AIDS ( $p=0.02$, Fisher's exact test; Table 2). Kaplan-Meier analysis of time to AIDS indicated that children with $\mathrm{R}$ replicating viruses progressed to AIDS earlier than those with $\mathrm{S}$ replicating strains, with a median AIDS-free survival time of 6 mo versus 13 mo for $\mathrm{R}$ and $\mathrm{S}$ replicating virus carriers, respectively $(p=0.02, \log$ rank test; Fig. $1 B$ ). Furthermore, we compared the first day of p24 Ag detection in culture supernatants of children who developed AIDS and those who did not. Early progressors had a mean time to $\mathrm{p} 24 \mathrm{Ag}$ positivity of $4.7 \pm 0.3 \mathrm{~d}$ (mean $\pm \mathrm{SD}$ ) versus $6.2 \pm 0.7 \mathrm{~d}$ for infants without early AIDS $(p=0.02$, unpaired $t$ test). Thus, HIV-1 could be detected more rapidly in cultures from infants with early onset of AIDS.

Next, we evaluated whether in vitro rapid replication kinetics may be associated with viral burden. There was not a statistically significant correlation between the first day of p24 $\mathrm{Ag}$ detection in PBMC culture supernatants and initial plasma

Table 1. Association between the different properties of HIV-1 replication kinetics

\begin{tabular}{ccccc}
\hline Replication rate & High & Low & $n$ & $p$ value* \\
\hline Rapid & $30(50 \%)$ & $5(9 \%)$ & $60(100 \%)$ & $<0.0001$ \\
Slow & $8(13 \%)$ & $17(28 \%)$ & & \\
\hline
\end{tabular}

* Fisher's exact test.

Table 2. HIV-1 phenotype during primary infection of vertically infected infants in relation to early AIDS outcome

\begin{tabular}{lccc}
\hline HIV-1 phenotype & With early AIDS & Without early AIDS & $n$ \\
\hline SI & $10(19 \%)$ & $1(2 \%)$ & $54(100 \%)$ \\
NSI & $24(44 \%)$ & $19(35 \%)$ & 5 value* \\
Rapid replication & $21(40 \%)$ & $5(9 \%)$ & $53(100 \%)$ \\
Slow replication & $13(25 \%)$ & $14(26 \%)$ & 0.04 \\
High replication & $21(40 \%)$ & $7(23 \%)$ & $53(100 \%)$ \\
Low replication & $13(24 \%)$ & & 0.02 \\
\end{tabular}

* Fisher's exact test. 


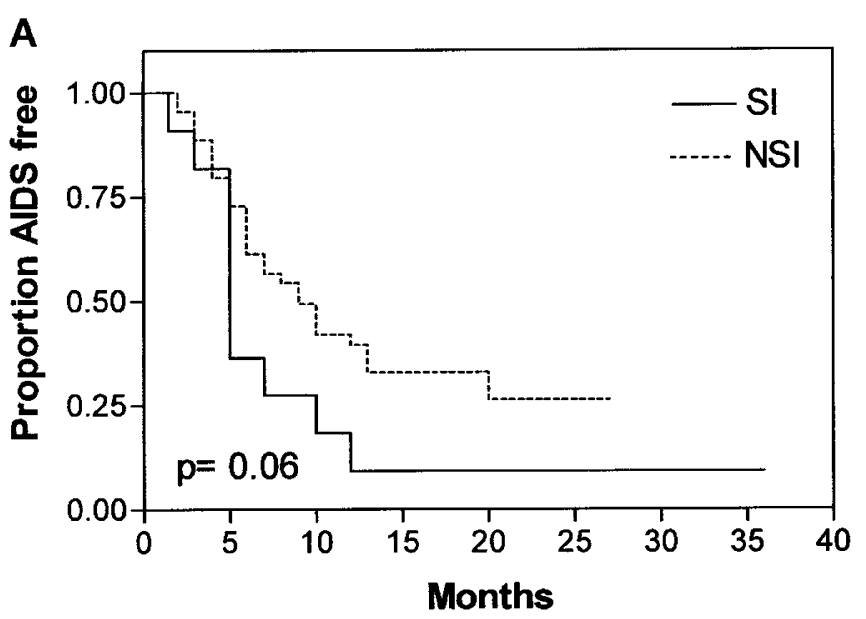

B
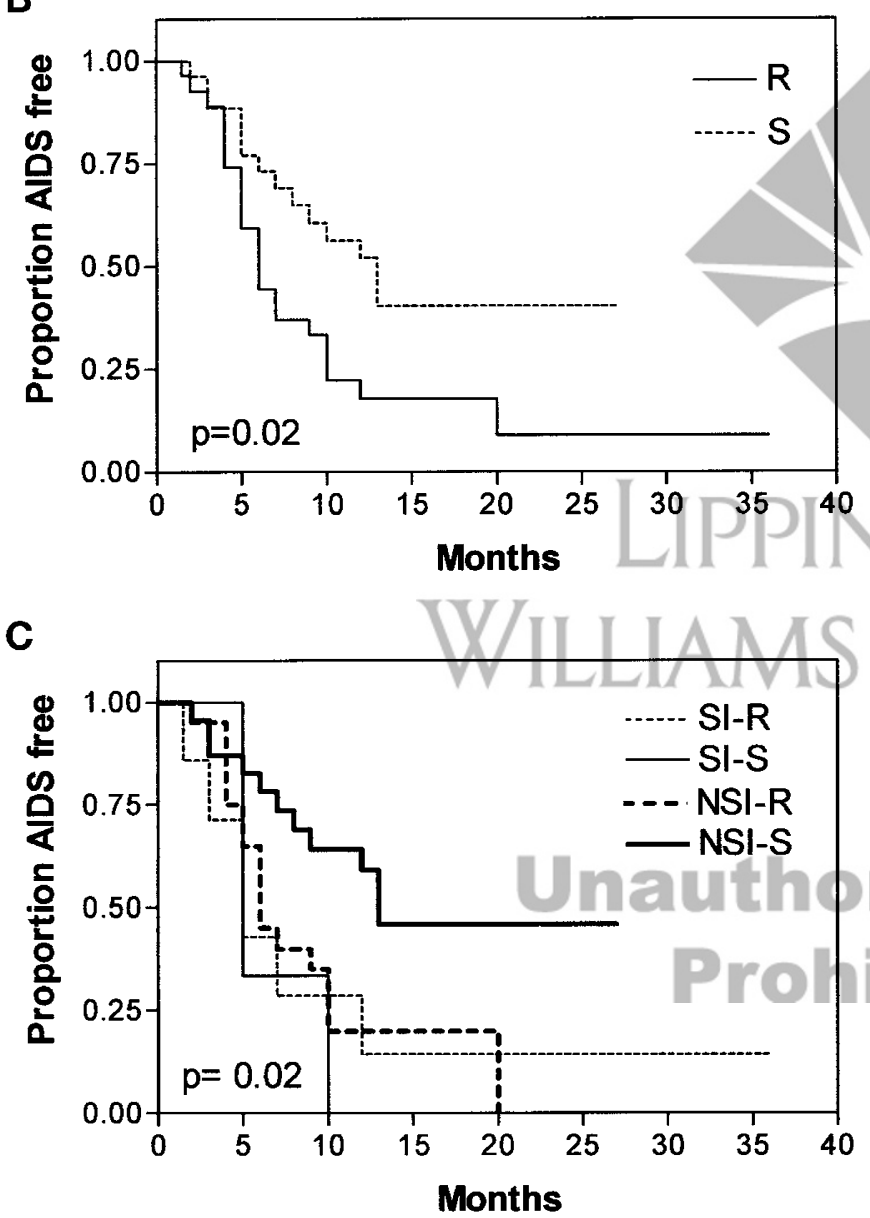

Figure 1. Effect of HIV-1 phenotype on disease progression. Kaplan-Meier plots for time in months after birth to AIDS in HIV-1 infected children in relation to SI (thick line) or NSI (dashed line) viral phenotype $(A)$; rapid $(R$, thick line) or slow (S, dashed line) viral replication rate $(B)$; and SI or NSI viral phenotype combined with $\mathrm{R}$ or $\mathrm{S}$ viral replication rate $(C)$. SI-R viral isolates are indicated by a thin dashed line, SI-S by a thin line, NSI-R strains by a thick dashed line, and NSI-S by a thick line. Log-rank test $p$ values from KaplanMeier analyses are shown.

viral load (data not shown). Therefore, a high plasma viremia did not necessarily reflect $\mathrm{R}$ replication rate of viral isolates. However, rapid growth of viral cultures might correlate with proviral load, which could not be tested because samples were not available. In terms of $\mathrm{H}$ or $\mathrm{L}$ viral replication rate and early onset of AIDS during primary infection, no significant association was observed by Fisher's exact test (Table 2) or by unpaired $t$ test when analyzing the mean $\mathrm{p} 24 \mathrm{Ag}$ maximum level detected during the month of culture in children with or without early AIDS (data not shown).

We next analyzed the effect of combined viral phenotypic properties on early clinical outcome. Kaplan-Meier analysis for time to AIDS revealed that only children who harbored NSI viral isolates with $\mathrm{S}$ replication rate showed a significant delay to AIDS progression ( $p=0.02$, log rank test; Fig. $1 C$ ). On the other hand, the presence of viral strains with rapid replication rate and/or SI capability constitutes poor prognosis markers.

Viral phenotype in relation to early immunosuppression. Rapid progression to AIDS during perinatal HIV-1 infection was significantly associated with advanced stages of immunosuppression $\left(\mathrm{CD}^{+}{ }^{+} \mathrm{T}\right.$-cell count $20 \%$ below normal, $p=0.05$, $\chi^{2}$ test, data not shown). Therefore, we analyzed the association between SI or NSI capability and replication rate of HIV-1 isolates with age-adjusted $\mathrm{CD} 4^{+}$T-cell counts. Results are shown in Table 3. In pediatric HIV-1 primary infection, SI viral phenotype and $\mathrm{R}$ replication rate were significantly associated with lower $\mathrm{CD}^{+}$T-cell counts, suggesting that these HIV-1 features may be relevant factors determining CD4 T-cell depletion. No association between $\mathrm{H}$ or $\mathrm{L}$ viral replication rate and immunosuppression in vertically infected infants was observed.

Viral load in relation to early AIDS outcome. The mean value of plasma HIV-1 burden during the first year of life was $5.70 \log _{10}$ copies $/ \mathrm{mL}$ (range, $3.99-7.00 \log _{10}$ ), with no significant difference between children who had or had not developed early AIDS (unpaired $t$ test, data not shown). Because initial viral burden was determined at different time points within the first year of life and plasma viral load kinetics varies considerably along this time of infection, we further assessed the data according to the age of the children when viral load was first measured (Fig. 2). Considering a plasma HIV-1 RNA cutoff level of $5.50 \log _{10}$ RNA copies $/ \mathrm{mL}$, the initial viral load measured within the first $5 \mathrm{mo}$ of life did not differ whether the infants developed early AIDS or not $(p=0.2$, Fisher's exact test). On the other hand, 83 and $32 \%$ of the infants older than 6 mo with plasma HIV-1 RNA levels $<5.50 \log _{10}$ and $>5.50$ $\log _{10}$ copies/mL, respectively, did not develop early AIDS ( $p$ $=0.06$, Fisher's exact test). These data suggest that a relative low plasma viral load in vertically infected children older than 6 mo of life may predict a less severe clinical stage.

Finally, to determine the combined effect of SI or NSI viral phenotype, replication kinetics, plasma viral load, $\mathrm{CD} 4^{+} \mathrm{T}$-cell counts, and prophylactic ZDV on disease progression, we performed a multivariate analysis by Cox proportional hazard model. Results are shown in Table 4. Rapid viral replication rate was the only variable that independently influenced early AIDS outcome (risk ratio, 2.48; 95\% confidence interval, $1.14-5.42 ; p=0.02)$.

\section{DISCUSSION}

The aim of this study was to evaluate the impact of HIV-1 replication phenotypes and initial viral burden during primary 
Table 3. $\mathrm{CD}^{+} \mathrm{T}$-cell counts in relation to HIV-1 phenotype in primary $H I V-1$ vertically infected children

\begin{tabular}{lccc}
\hline HIV-1 phenotype & $\begin{array}{c}\text { CD4 } \\
\text { Mean } \pm \text { SE }\end{array}$ & $n$ & $p$ value $\dagger$ \\
\hline SI & $34.3 \pm 7.7$ & 11 & 0.01 \\
NSI & $57.2 \pm 4.0$ & 40 & \\
Rapid replication & $45.9 \pm 5.3$ & 25 & 0.05 \\
Slow replication & $60.1 \pm 5.0$ & 26 & \\
High replication & $53.2 \pm 5.0$ & 31 & 0.90 \\
Low replication & $53.9 \pm 5.7$ & 20 & \\
\hline
\end{tabular}

* Percentage of age-adjusted normal median $\mathrm{CD}^{+}{ }^{+} \mathrm{T}$-cell counts was calculated for each patient.

$\dagger$ Unpaired $t$ test.

\begin{tabular}{|c|c|}
\hline & 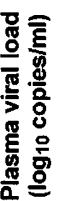 \\
\hline
\end{tabular}

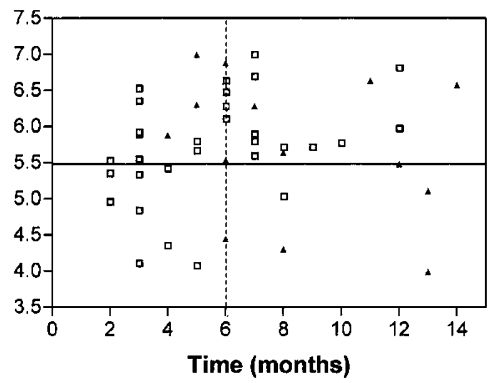

- With early AIDS

- Without early AIDS

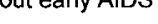

Figure 2. Initial plasma viral load measurement during primary infection. Values of plasma viral burden in $\log _{10}$ copies $/ \mathrm{mL}$ are indicated for each patient on the $y$ axis in relation to the age of measurement on the $x$ axis Children who developed AIDS within the first year of life are indicated with an open square, and those who did not develop early AIDS with a filled triangle.

Table 4. Influence of different HIV-1 features and ZDV prophylactic therapy in relation to AIDS outcome by Cox proportional hazard regression analysis

\begin{tabular}{lccc}
\hline \multicolumn{1}{c}{ Comparison } & Risk ratio & $95 \%$ CI & $p$ value \\
\hline SI $v$ NSI & 1.85 & $0.83-4.13$ & 0.13 \\
Rapid $v$ s slow replication & 2.48 & $1.14-5.42$ & 0.02 \\
High $v s$ low replication & 0.49 & $0.23-1.06$ & 0.07 \\
$\mathrm{CD}^{+}$count $\leq 20 \% v s>20 \%$ & 1.16 & $0.55-2.49$ & 0.69 \\
Viral load $\geq 5.5 v s<5.5^{\text {Prophylactic ZDV } v s \text { no ZDV }}$ & 0.86 & $0.39-1.88$ & 0.70 \\
$\quad$ therapy & 0.99 & $0.49-2.03$ & 0.99 \\
\hline
\end{tabular}

CI, confidence interval.

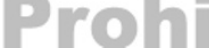

infection in the early onset of immunosuppression and clinical AIDS in a cohort of vertically infected infants. The presence of HIV-1 variants with rapid replication capability and/or an SI phenotype is indicative of a poor prognosis favoring $\mathrm{CD}^{+}$ T-cell depletion and rapid onset of AIDS. In addition, a relatively high plasma viral load after 6 mo of life tends to predict an early development of AIDS.

Contrary to other pediatric studies $(20,27)$ that reported the isolation of only NSI strains during the first year of HIV-1 infection, we observed that one fifth of HIV-1 isolates induced syncytium formation on MT-2 cells. Although NSI viral strains are the replication phenotypes most frequently transmitted, SI strains have also been transmitted by different routes (28-31). However, this phenotype tends to disappear soon after transmission, with only the NSI viral strains persisting $(9,30,32$, 33). The presence of SI variants, as early as 1 mo of age, suggests that they could be the transmitter viruses or that an early and rapid switch from NSI to SI virus after infection has occurred, as observed by Resino et al. (18). Nevertheless, both possibilities are not mutually exclusive.

It is accepted that SI HIV-1 strains are T-tropic, showing a more rapid and higher replication rate than NSI M-tropic strains. However, and in accordance with Connor and Ho (34), in our study HIV-1 primary isolates replicated rapidly, independently of syncytium formation. The correlation observed between cell tropism, replication rate, and cytopathicity seems to be more representative of laboratory-adapted HIV-1 strains than of primary isolates (35), which may explain the weak correlation found between the viral features analyzed in our study. SI capability and $\mathrm{R} / \mathrm{H}$ replication rate are considered HIV-1 phenotypic properties of high virulence. In adults their appearance during the course of infection usually precedes a rapid decline in $\mathrm{CD}^{+}{ }^{+} \mathrm{T}$-cell counts and the onset of AIDS (4-6, 11-14, 36). In HIV-1 perinatally infected children, the association between different viral features and disease progression remains controversial (15-20). We observed that most of the children harboring SI viral strains progressed to AIDS within the first year of life. However, more than a half of the infants with NSI viruses also developed early AIDS. Furthermore, HIV-1 with rapid replication rate independent of SI capability can predict pediatric disease progression with early development of immunosuppression and clinical AIDS. In our cohort, the proportion of children with early AIDS, although higher than in other reports (1-3), is somehow expected for children attending a tertiary care center without an obstetric unit. Therefore, it does not represent the AIDS development rate in an Argentinean pediatric population. Overall this does not affect the aim of this study, which evaluates the influence of viral biologic features on the clinical outcome of infection. In adults during primary HIV-1 infection, once the level of viral burden reaches the steady state, it may predict the clinical course of HIV-1 infection (8). In vertically infected children, although little is known about viral load patterns, plasma viral load increases rapidly after birth, reaching a peak within the first 6 mo of age (37), thereafter followed by a decline during the first $5 \mathrm{y}$ of life $(38)$. Some authors $(18,39)$ have reported that viral load during the first months of life may be a good surrogate marker of disease progression in perinatally infected infants. In our pediatric cohort, the initial viral burden determined during the first year of life was high without showing prognostic value; it was only after 6 mo of life that it tended to be associated with disease progression.

\section{CONCLUSIONS}

In conclusion, during primary infection, in infants similar to adults, in vitro HIV-1 biologic features play an important role as predictors of early immunologic and clinical outcome so that viral phenotypic properties become relevant markers to be taken into account when designing therapeutic strategies.

Acknowledgments. The authors thank C. Galvez for technical assistance, A. del Pozo for providing us blood samples from HIV-1 seronegative blood donors, and Roberto C. Arduino and Christiane Dosne Pasqualini for critical revision of the manuscript. 


\section{REFERENCES}

1. Duliege AM, Messiah A, Blanche S, Tardieu M, Griscelli C, Spira A 1992 Natural history of human immunodeficiency virus type 1 infection in children: prognostic value of laboratory tests on the bimodal progression of disease. Pediatr Infect Dis J 11:630-635

2. Blanche S, Rouzioux C, Guihard Moscato ML, Veber F, Mayaux MJ, Jacomet C, Tricoire J, Deville A, Vial M, Firtion G, de Crepy A, Douard D, Robin M, Courpotin C, Ciraru-Vigneron N, le Deist F, Griscelli C, and the HIV Infection in Newborns French Collaborative Study Group 1989 A prospective study of infants born to women seropositive for human immunodeficiency virus type 1 . N Engl J Med 320:1643-1648

3. European Collaborative Study 1991 Children born to women with HIV-1 infection: natural history and risk of transmission. Lancet 337:253-260

4. Asjö B, Morfeldt-Manson L, Albert J, Biberfeld G, Karlsson A, Lidman K, Fenyö EM 1986 Replicative capacity of human immunodeficiency virus from patients with varying severity of HIV infection. Lancet 2:660-662

5. Cheng-Mayer C, Seto D, Tateno M, Levy J 1988 Biologic features of HIV-1 that correlate with virulence in the host. Science 240:80-82

6. Tersmette M, Lange JM, de Goede REY, de Wolf F, Eeftink-Schattenkerk JKM, Schellekens PA, Coutinho RA, Huisman JG, Goudsmit J, Miedema F 1989 Association between biological properties of human immunodeficiency virus variants and risk for AIDS and AIDS mortality. Lancet 1:983-985

7. Fauci AS 1996 Host factors and the pathogenesis of HIV-induced disease. Nature 384:529-534

8. Mellors JN, Kingsley LA, Rinaldo CRJ, Todd JA, Hoo BS, Kokka RP, Gupta P 1995 Quantitation of HIV-1 RNA in plasma predicts outcome after seroconversion. Ann Intern Med 122:573-579

9. van't Wout AB, Kootstra NA, Mulder-Kampinga A, Albrecht-van Lent N, Scherpbier HJ, Veenstra J, Boer K, Coutinho RA, Miedema F, Schuitemaker H 1994 Macrophage-tropic variants initiate human immunodeficiency virus type 1 infection afte sexual, parenteral, and vertical transmission. J Clin Invest 94:2060-2067

10. Zhu T, Mo H, Wang N, Nam DS, Cao Y, Koup RA, Ho D 1993 Genotypic and phenotypic characterization of HIV-1 in patients with primary infection. Science 261:1179-1181

11. Tersmette M, de Goede REY, Al BJM, Winkel IN, Gruters RA, Cuypers HT, Huisman HG, Miedema F 1988 Differential syncytium-inducing capacity of human immunodeficiency virus isolates: frequent detection of syncytium-inducing isolates in patients with acquired immunodeficiency syndrome (AIDS) and AIDS-related complex. J Virol 62:2026-2032

12. Schuitemaker H, Koot M, Kootstra NA, Dercksen MW, de Goede RE, van Steenwijk RP, Lange JM, Schattenkerk JK, Miedema F, Tersmette M 1992 Biological phenotype of human immunodeficiency virus type 1 clones at different stages of infection: progression of disease is associated with a shift from monocytotropic to T-cell-tropic virus population. J Virol 66:1354-1360

13. Koot M, Keet IPM, Vos AHV, de Goede REY, Roōs MTL, Coutinho MD, Miedema F, Schellekens PA, Tersmette M 1993 Prognostic value of HIV-1 syncytium-inducing phenotype for rate of $\mathrm{CD}^{+}$cell depletion and progression to AIDS. Ann Intern Med 118:681-688

14. Richman D, Bozzette SA 1994 The impact of the syncytium-inducing phenotype of human immunodeficiency virus on disease progression. J Infect Dis 169:968-974

15. De Rossi A, Giaquinto C, Ometto L, Mammano F, Zanotto C, Dunn D, ChiecoBianchi L 1993 Replication and tropism of human immunodeficiency virus type 1 as predictors of disease outcome in infants with vertically acquired infection. J Pediatr 123:929-936

16. Ballota C, Vigano A, Riva C, Colombo MC, Salvaggio A, de Pasquale MP, Crupi L, Papagno L, Galli M, Moroni M, Principi N 1996 HIV type 1 phenotype correlates with the stage of infection in vertically infected children. AIDS Res Hum Retroviruses 12:1247-1253

17. Muñoz-Fernández MA, Navarro J, Obregón E, Arias RA, Gurbindo MD, Sampelayo TH, Fernández-Cruz E 1997 Immunological and virological markers of disease progression in HIV-infected children. Acta Paediatr Suppl 421:46-51

18. Resino S, Gurbindo D, Bellón Cano JM, Sánchez-Ramón S, Muñoz-Fernández MA 2000 Predictive markers of clinical outcome in vertically HIV-1-infected infants: a prospective longitudinal study. Pediatr Res 47:509-515

19. Gupta P, Urbach A, Cosentino L, Thampatty P, Brady M 1993 HIV-1 isolates from children with or without AIDS have similar in vitro biologic properties. AIDS $7: 1561-1564$
20. Fitzgibbon JE, Gaur S, Gavai M, Gregory P, Frenkel LD, John Jr JF 1998 Effect of the HIV-1 syncytium-inducing phenotype on disease stage in vertically-infected children. J Med Virol 55:56-63

21. Connor EM, Sperling RS, Gelber R, Kiselev P, Scott G, O’Sullivan MJ, VanDyke R, Bey M, Shearer W, Jacobson RL, Jimenez E, O'Neill E, Bazin B, Delfraissy J-F, Culnane M, Coombs R, Elkins M, Moye J, Stratton P, Balsley J, for the Pediatric AIDS Clinical Trials Group Protocol 076 Study Group 1994 Reduction of maternalinfant transmission of human immunodeficiency virus type 1 with zidovudine treatment. N Engl J Med 331:1173-1180

22. Denny T, Yogev R, Gelman R, Skuza C, Oleske J, Chadwick E, Cheng S-C, Connor E 1992 Lymphocyte subsets in healthy children during the first five years of life. JAMA 267:1484-1488

23. US Centers for Disease Control and Prevention 1994 Classification system for human immunodeficiency virus (HIV) infection in children under 13 years of age. MMWR Morb Mortal Wkly Rep 43:1-10

24. Hollinger FB, Bremer JW, Myers LE, Gold JW, McQuay L 1992 Standardization of sensitive human immunodeficiency virus coculture procedures and establishment of a multicenter quality assurance program for the AIDS Clinical Trials Group. The NIH/NIAID/DAIDS/ACTG Virology Laboratories. J Clin Microbiol 30:1787-1794

25. Japour AJ, Fiscus SA, Arduino J-M, Mayers DL, Reichelderfer PS, Kuritzkes DR 1994 Standardized microtiter assay for determination of syncytium-inducing phenotypes of clinical human immunodeficiency virus type 1 isolates. J Clin Microbiol 32:2291-2294

26. Albert J, Fenyo EM 1990 Simple, sensitive, and specific detection of human immunodeficiency virus type 1 in clinical specimens by polymerase chain reaction with nested primers. J Clin Microbiol 28:1560-1564

27. Spencer LT, Ogino MT, Dankner WM, Spector SA 1994 Clinical significance of human immunodeficiency virus type 1 phenotypes in infected children. J Infect Dis 169:491-495

28. Roos MTL, Lange JMA, de Goede REY, Coutinho RA, Schellekens PTA, Miedema F, Tersmette M 1992 Viral phenotype and immune response in primary human immunodeficiency virus type 1 infection. J Infect Dis 165:427-432

29. Nielsen C, Pedersen C, Lundgren JD, Gerstoft J 1993 Biological properties of HIV

isolates in primary HIV infection: consequences for the subsequent course of infection. AIDS 7:1035-1040

30. Cornelissen M, Mulder-Kampinga G, Veenstra J, Zorgdrager F, Kuiken C, Hartman S, Dekker J, van der Hoek L, Sol C, Coutinho R, Goudsmit J 1995 Syncytiuminducing (SI) phenotype suppression at seroconversion after intramuscular inoculation of a non-syncytium-inducing/SI phenotypically mixed human immunodeficiency virus population. J Virol 69:1810-1818

31. Fiore JR, Buccoliero G, Pezzotti P, Rezza G, Saracino A, Pastore G, Fenyo EM, Angarano G 1999 HIV-1 disease progression in women: role of the viral phenotype of the HIV-positive steady partner. AIDS 13:1801-1802

32. Baur A, Schwarz N, Ellinger S, Korn K, Harrer T, Mang K, Jahn G 1989 Continuous clearance of HIV in a vertically infected child. Lancet 2:1045

33. Rübsamen-Waigmann H, Williams WR, Bretram U, Von Briessen H 1989 Reversal of HIV-phenotype to fulminant replication on macrophages in perinatal transmission. Lancet 2:1155-1156

34. Connor RI, Ho DD 1994 Human immunodeficiency virus type 1 variants with increased replicative capacity develop during the asymptomatic stage before disease progression. J Virol 68:4400-4408

35. Van't Wout AB, Blaak H, Ran LJ, Brouwer M, Kuiken C, Schuitemaker H 1998 Evolution of syncytium-inducing and non-syncytium-inducing biological virus clones in relation to replication kinetics during the course of human immunodeficiency virus type 1 infection. J Virol 72:5099-5107

36. Shankarappa R, Margolick JB, Gange SY, Rodrigo AG, Upchurch D, Farzadegan H, Gupta P, Rinaldo CR, Learn GH, He X, Huang X-L, Mullins JI 1999 Consistent viral evolutionary changes associated with the progression of human immunodeficiency virus type 1 infection. J Virol 73:10489-10502

37. Shearer WT, Quinn TC, LaRussa P, Lew JF, Mofenson L, Almy S, Rich K, Handelsman E, Diaz C, Pagano M, Smeriglio V, Kalish L, for the Women and Infants Transmission Study Group 1997 Viral load and disease progression in infants infected with human immunodeficiency virus type 1. N Engl J Med 336:1337-1342

38. European Collaborative Study 2002 Level and pattern of HIV-1 RNA viral load over age: differences between girls and boys? AIDS 16:97-104

39. Muñoz-Fernández MA, Obregón E, Navarro J, Börner C, Gurbindo MD, Sampelayo TH, Fernández Cruz E 1996 Relationship of virologic, immunologic, and clinical parameters in infants with vertically acquired human immunodeficiency virus type 1 infection. Pediatr Res 40:597-602 